\title{
Emission of volatile organic compounds from domestic coal stove with the actual alternation of flaming and smoldering combustion processes $^{\text {is }}$
}

\author{
Chengtang Liu ${ }^{\text {a, c }}$, Chenglong Zhang ${ }^{\text {a, c }}$, Yujing Mu ${ }^{\text {a, b, c, *, Junfeng Liu }}{ }^{\text {a, c }}$, \\ Yuanyuan Zhang a, $\mathrm{c}$ \\ ${ }^{a}$ Research Center for Eco-Environmental Sciences, Chinese Academy of Sciences, Beijing 100085, China \\ ${ }^{\mathrm{b}}$ Center for Excellence in Regional Atmospheric Environment, Institute of Urban Environment, Chinese Academy of Sciences, Xiamen 361021, China \\ ${ }^{\mathrm{c}}$ University of Chinese Academy of Sciences, Beijing 100085, China
}

\section{A R T I C L E I N F O}

\section{Article history:}

Received 17 June 2016

Received in revised form 30 November 2016

Accepted 30 November 2016

Available online 14 December 2016

\section{Keywords:}

NMHCs

Carbonyls

Domestic coal combustion

Raw bituminous coal

Emission factor

\begin{abstract}
A B S T R A C T
Volatile organic compounds (VOCs) emissions from the chimney of a prevailing domestic stove fuelled with raw bituminous coal were measured under flaming and smoldering combustion processes in a farmer's house. The results indicated that the concentrations of VOCs quickly increased after the coal loading and achieved their peak values in a few minutes. The peak concentrations of the VOCs under the smoldering combustion process were significantly higher than those under the flaming combustion process. Alkanes accounted for the largest proportion (43.05\%) under the smoldering combustion, followed by aromatics $(28.86 \%)$, alkenes (21.91\%), carbonyls $(5.81 \%)$ and acetylene $(0.37 \%)$. The emission factors of the total VOCs under the smoldering combustion processes $\left(5402.9 \pm 2031.8 \mathrm{mg} \mathrm{kg}^{-1}\right)$ were nearly one order of magnitude greater than those under the flaming combustion processes $\left(559.2 \pm 385.9 \mathrm{mg} \mathrm{kg}^{-1}\right)$. Based on the VOCs emission factors obtained in this study and the regional domestic coal consumption, the total VOCs emissions from domestic coal stoves was roughly estimated to be $1.25 \times 10^{8} \mathrm{~kg} \mathrm{a}^{-1}$ in the Beijing-Tianjin-Hebei region.
\end{abstract}

(c) 2016 Elsevier Ltd. All rights reserved.

\section{Introduction}

Coal is the prevailing energy for heating in winter over the vast rural areas in the north of China and its consumption has evidently increased with the increase in residents' income in recent years (Ben and Kayoko, 2015). Ten years ago, small and simple coal stoves were manually made by bricks and fuelled by anthracite coal for heating, and the coal consumption of each family was usually less than 1 ton during the entire winter. In recent years, larger commercial coal stoves fuelled by bituminous coal have been increasingly adopted by residents, with a coal consumption of $2-4$ tons per family during the wintertime. Because the combustion efficiency of current domestic coal stoves is very low and no control measures have been adopted (Bond et al., 2004; Finkelman et al.,

\footnotetext{
th This paper has been recommended for acceptance by David Carpenter.

* Corresponding author. Research Center for Eco-Environmental Sciences, Chinese Academy of Sciences, Beijing 100085, China.

E-mail address: yjmu@rcees.ac.cn (Y. Mu).
}

1999, 2002), smoke from the chimneys of the stoves can be seen everywhere in the rural areas of Beijing-Tianjin-Hebei during the winter season. Various pollutants have been identified in the fluegas from domestic stoves, including particulate matter (PM), polycyclic aromatic hydrocarbons (PAHs), carbon monoxide (CO), sulfur dioxide $\left(\mathrm{SO}_{2}\right)$ and so on, which are harmful to human health (Chen et al., 2004, 2005; Huang et al., 2014a; Lee et al., 2005; Oros and Simoneit, 2000; Pandit et al., 2001; Tian et al., 2008; Vanker et al., 2015; Wang et al., 2016; Zhang et al., 2012; Zhang and Smith, 2007). It has been found that indoor air pollution levels (e.g., PM and $\mathrm{SO}_{2}$ ) in households using coal for heating or cooking generally exceed that of China's indoor air quality standards, and several investigations have indicated that household smoke is associated with health effects such as respiratory illnesses, lung cancer, chronic obstructive pulmonary disease, weakening of the immune system, etc. (Barreca et al., 2014; Dong et al., 2013; Hosgood et al., 2011, 2013; Subbaraman, 2014; Zhang and Smith, 2007). The pollutants emitted from domestic coal stoves not only threaten the health of residents, but also deteriorate the regional air 
quality (Gaffney and Marley, 2009). Previous studies revealed that the emission factors (EFs) of particulate matter with an aerodynamic diameter less than $2.5 \mu \mathrm{m}\left(\mathrm{PM}_{2.5}\right)$, PAHs, $\mathrm{COS}$ and $\mathrm{CO}$ from domestic coal stoves were approximately 1-3 orders of magnitude greater than those from power plants (Zhang et al., 2000, 2008; Du et al., 2016). Considering the domestic coal consumption accounts for $11 \%\left(4.2 \times 10^{10} \mathrm{~kg} \mathrm{a}^{-1}\right)$ of the total coal consumption in the area of Beijing-Tianjin-Hebei (http://www.qstheory.cn/st/dfst/201306/ t20130607_238302.htm), the impact of the emissions of various pollutants from domestic coal stoves on the regional air quality have aroused great concern (Boynard et al., 2014; Li et al., 2015, 2014a, 2014b; Liu et al., 2008a; Tao et al., 2012; Xu et al., 2011).

Besides $\mathrm{PM}_{2.5}$, PAHs and $\mathrm{CO}$, remarkable emissions of volatile organic compounds (VOCs, non-methane hydrocarbons (NMHCs) and carbonyls) from domestic coal stoves have also been reported (Zhang et al., 2000; Tsai et al., 2003; Wang et al., 2013). After releasing into the atmosphere, VOCs can be oxidized by $\mathrm{OH}, \mathrm{NO}_{3}$ and $\mathrm{O}_{3}$ to form various secondary pollutants (such as peroxides, secondary organic aerosol ( $\mathrm{SOA}$ ), carbonyls, $\mathrm{O}_{3}$ ) that deteriorate the air quality, as well as harm human health and vegetation (Huang et al., 2014b). In addition, some VOCs (e.g., benzene and formaldehyde) emitted from domestic coal combustion have been verified to be toxic, carcinogenic or mutagenic (Møller et al., 2008). However, few studies have investigated VOCs emissions from domestic coal stoves, and those that did only focused on the flaming combustion process (Zhang et al., 2000; Tsai et al., 2003; Wang et al., 2013). Actually, coal combustion in domestic coal stoves usually occurs through alternation of the flaming and smoldering combustion processes in rural areas. Compared with the flaming combustion process, which uses sufficient air supply, the evident decrease in air supply during the smoldering combustion process can result in the flameless burning of coal, slow rate of coal combustion and low temperature of hearth. As many factors, including temperature, air supply, and flame affect VOCs emissions from coal combustion (Oros and Simoneit, 2000; Gaffney and Marley, 2009), VOCs emissions from domestic coal stoves, based on a kind of flaming combustion process, were not suspected to be representative of actual emissions.

To reflect actual VOCs emissions from domestic coal stoves, we investigated the emission characteristics, composition and emission factors (EFs) of VOCs from a prevailing domestic stove fuelled with raw bituminous coal under flaming and smoldering combustion processes in a farmer's house. In addition, the regional VOCs emission from domestic coal combustion was roughly estimated based on the VOCs emission factor and the domestic coal consumption.

\section{Experimental section}

\subsection{Stove and coal}

A kind of prevailing stove (Fig. 1a) used by residents for heating during winter in the rural areas of Beijing-Tianjin-Hebei was selected for this study. The stove consists of a hearth, fire grate, an ash door, a heat exchanger and a chimney. The hearth (approximately $18.5 \mathrm{~L}$ for loading coal) is located at the centre of the stove and is surrounded by a thermal-insulated ceramic liner which is covered by a metallic outer cover. The fire grate is at the bottom of the hearth for supporting lump coal and felling the ash of the coal combustion. The ash door is under the fire grate for removing the ash and controlling the air flow for combustion. The heat exchanger is on the top side of the metallic outer cover to supply heat for an area of approximately $150 \mathrm{~m}^{2}$. The chimney $(12 \mathrm{~cm}$ in I.D. and $6 \mathrm{~m}$ in length) is connected with the heat exchanger to drive the air from the ash door through the hearth for coal combustion. Besides heating, the stove is also used for cooking by residents in the morning, noon and evening when the ash door of the stove is fully opened for fast combustion (designated as the flaming combustion process). The fire in the stove was usually kept from extinguishing after ignition by residents during the entire winter, and hence the ash door is always closed (called the smoldering combustion process) after cooking to save coal and labour. Bituminous coal from Inner-Mongolia is currently the prevailing coal used for heating by the residents in the rural areas of Beijing-Tianjin-Hebei. Large blocks of bituminous coal were broken into pieces of $1-5 \mathrm{~cm}$ in diameter, and lumps of diameters greater than $3 \mathrm{~cm}$ (Fig. 1b) were used for the flaming combustion process; Smaller lumps (Fig. 1c) were loaded into the stove for the smoldering combustion process.

\subsection{Sampling}

VOCs emissions from the chimney of the stove were investigated in the house of a Dongbaituo village resident in Hebei Province during the winter of 2013, and coal combustion in the stove strictly followed the operation habit of local residents, alternating the flaming combustion process and smoldering combustion process. A stainless-steel tube was inserted into the centre of the chimney, $20 \mathrm{~cm}$ below the top of the chimney to collect the air samples, and each air sample was collected into a vacuum SUMMA canister (3.2 L, Entech Inc.) after passing through a filter $(0.45 \mu \mathrm{m})$. To reflect the VOCs emissions from coal combustion in the stove, a series of air samples from the chimney were collected at different intervals, with a high sampling frequency at the beginning of each coal loading when the smoke was strongest. The carbonyls in the flue-gas were collected with 2,4-dinitrophenylhenylhydrazine (DNPH)-coated Sep-Pak silica gel cartridges. Every $1000 \mathrm{~cm}^{3}$ gas was sampled into the coated cartridge. After sampling, the cartridges were immediately sealed with silicon caps, and stored in a refrigerator before analysis. A thermocouple was inserted into the chimney (20 cm below the top of chimney) to measure the temperature of the flue-gas. A hand-held velocity meter (Testo 410, Germany) was used to measure the flow rate of the flue-gas.

\subsection{VOCs measurements}

The air samples were analyzed by a gas chromatography equipped with a flame ionization detector (GC-FID) after preconcentration/thermal-desorption. Details about sample analysis and calibration can be found in Liu et al. (2016). Briefly, 5 or $10 \mathrm{~cm}^{3}$ of the air samples were injected into a $100 \mathrm{~cm}^{3}$ syringe which contained high purity $\mathrm{N}_{2}$, and enriched into an adsorption tube filled with 60-80 mesh Carbopack ${ }^{\mathrm{TM}} \mathrm{B}$ at $183 \mathrm{~K}$. Then, the adsorption tube was quickly heated to $423 \mathrm{~K}$ and the desorbed NMHCs were injected into a capillary column (OV-1, $30 \mathrm{~m} \times 0.32 \mathrm{~mm}$ I.D.) for separation: $3 \mathrm{~min}$ at $213 \mathrm{~K}$, ramp at $12 \mathrm{~K} \mathrm{~min}^{-1}$ to $253 \mathrm{~K}$, ramp at $6 \mathrm{~K} \mathrm{~min}^{-1}$ to $303 \mathrm{~K}$, ramp at $10 \mathrm{~K} \mathrm{~min}^{-1}$ to $443 \mathrm{~K}$, then hold for $2 \mathrm{~min}$. The NMHCs were detected by FID at $523 \mathrm{~K}$. The standard calibration curves derived from the enrichment of the standard gas mixture of 57 NMHCs ( 1.0 ppmv for each NMHC, provided by Spectra Gases Inc., USA) were found to be in good linear correlations $\left(R^{2}>0.99\right)$; These curves were used for the quantification of the air samples. The method detection limit (MDL) for each species ranged from 2 to $10 \mathrm{ppbv}$, and the relative standard deviation (RSD) was less than $5 \%$.

The analysis procedure of atmospheric carbonyls was based on the EPA TO-11A method (EPA, 1999), and the details have been described in our previous publications (Pang and Mu, 2006, 2007). The carbonyl derivatives in each DNPH cartridge were eluted slowly with $5.0 \mathrm{~cm}^{3}$ acetonitrile, and analyzed by an HPLC system (Waters Alliance 2695, USA) with a Supelcosil LC-18 reverse phase column 

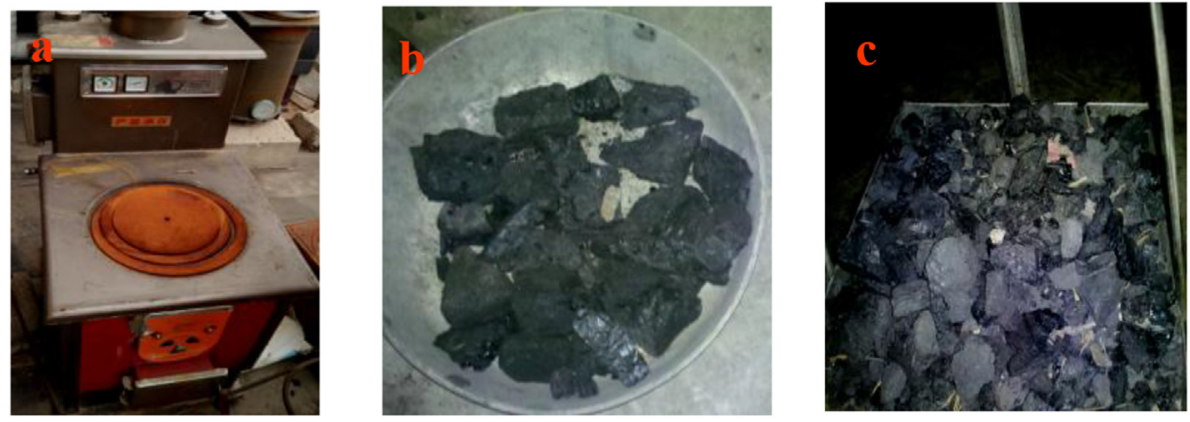

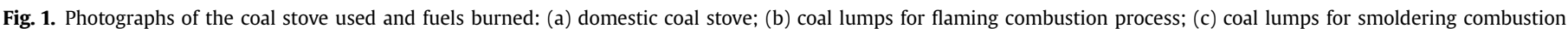
process.

(5 $\mu \mathrm{m}, 250 \mathrm{~mm} \times 4.6 \mathrm{~mm}$ ) and a photodiode array UV detector (at $360 \mathrm{~nm}$ ). An authentic standard solution containing carbonyl derivatives of formaldehyde, acetaldehyde, acetone, propionaldehyde, butyraldehyde and benzaldehyde (T011/IP-6A Aldehyde/KetoneDNPH Mix, Supelco Analytical, USA) was used to identify the carbonyls. The quantification of the identified compounds was carried out by using analytical curves derived from five levels of external standard concentrations. The detected limits for various carbonyls were in the range of 4-6 ppbv with a sampling volume of $1000 \mathrm{~cm}^{3}$, and the RSDs were less than $5 \%$.

\subsection{Emission factors (EFs)}

The EFs ( $\mathrm{mg} \mathrm{kg}^{-1}$ ) of the VOCs were calculated by the following equation.

$E F=\frac{\sum C_{t} Q_{t} \Delta \mathrm{t}}{M_{C}}$

where $C_{t}\left(\mathrm{mg} \mathrm{m}^{-3}\right)$ is the mean concentration of the VOCs species in the air samples collected during the consecutive sampling interval, $Q_{t}\left(\mathrm{~m}^{3} \mathrm{~min}^{-1}\right)$ is the mean flow rate of the flue-gas during the sampling interval, $\triangle t(\mathrm{~min})$ is the sampling interval time and $M_{c}$ $(\mathrm{kg})$ is the coal consumption. All flue-gas volumes were corrected to standard conditions ( $298 \mathrm{~K}$ and $1 \mathrm{~atm}$ ).

\section{Results and discussion}

\subsection{The emission characteristics of NMHCs and carbonyls}

A typical chromatogram of NMHCs in the flue-gas of the stove during coal combustion is illustrated in Fig. 2. Compared with the standard chromatogram, evident peaks of 38 NMHCs could be identified in the flue-gas from the chimney, including 21 alkanes, 1 alkyne (acetylene), 10 alkenes and 6 aromatics. In addition, six carbonyls, including formaldehyde, acetaldehyde, acetone, propionaldehyde, butyraldehyde and benzaldehyde, were also identified in the flue-gas.

The typical variation characteristics of NMHCs and carbonyls in the flue-gas, the temperature of the hearth, the temperature and flow rate of the flue-gas during two consecutive combustion processes are shown in Fig. 3. Because the smoldering combustion process (Fig. 3A) followed the flaming combustion process, the initial temperatures of the hearth and the flue-gas were relatively high. The initially quick decrease of the hearth temperature and the flue-gas temperature as well as the flow rate of the flue-gas was ascribed to the coal loading and the closing of the ash door, requisite for the smoldering combustion process. As shown in Fig. $3 \mathrm{~B}$ and $\mathrm{C}$, the concentrations of NMHCs quickly increased and achieved their peak values at 5 min after the coal loading, and then gradually decreased for aromatics and sharply decreased for alkanes and alkenes, indicating that their emissions were mainly from the initial pyrolysis of the freshly loaded coal. Compared with their peak values at $5 \mathrm{~min}$, the concentrations of alkanes and alkenes decreased by approximately $95 \%$ at $30 \mathrm{~min}$, whereas aromatics only decreased by approximately $65 \%$. The faster rates of decrease for alkanes and alkenes than those for aromatics after their peak values indicated that the depletion of alkanes and alkenes formed by the pyrolysis of coal was quicker than that of aromatics. Additionally, the proportion variation of typical species during the smoldering combustion process was remarkable. For example, the ratio of benzene to toluene (ppbv/ppbv) was approximately 2.6 at the beginning of the coal loading, then gradually decreased to approximately 0.3 during the smoldering combustion process. For carbonyls, the peak concentrations of formaldehyde (1.48 ppmv), acetaldehyde (3.80 ppmv) and propionaldehyde (1.45 ppmv) appeared just after the coal loading (at $0.5 \mathrm{~min}$ ), whereas the peak concentrations of acetone (18.69 ppmv), butyraldehyde (4.45 ppmv) and benzaldehyde ( $0.57 \mathrm{ppmv}$ ) were observed at $5 \mathrm{~min}$ after the coal loading. The time difference for the peak concentrations of carbonyls was probably due to their different formation rates from oxidation of their corresponding NMHCs during the smoldering combustion process.

The flaming combustion process (Fig. 3E) followed the above smoldering combustion process, and the initially fast increase in the temperatures of the hearth and the flue-gas as well as the flow rate of the flue-gas were mainly ascribed to the opening of the ash door, requisite for the flaming combustion process. Similar to the smoldering combustion process, the concentrations of aromatics, alkanes and alkenes sharply increased and reached peak values at 5 min after the coal loading. However, in contrast to the smoldering combustion process, the peak concentrations of the alkanes and alkenes decreased by approximately one magnitude and the rates of decreasing concentration for the aromatics, alkanes and alkenes after their peak values were fast, resulting in $\sim 90 \%$ reduction within $15 \mathrm{~min}$. Evident flame from the stove could be seen at $5 \mathrm{~min}$ after the coal loading, and it could initiate combustion of aromatics, alkanes and alkenes, resulting in their remarkable reduction. For carbonyls, the peak values for formaldehyde (3.87 ppmv), acetaldehyde (2.30 ppmv) and benzaldehyde ( $0.44 \mathrm{ppmv})$ occurred at $5 \mathrm{~min}$, and for acetone (1.48 ppmv), propionaldehyde (0.97 ppmv), and butyraldehyde ( $0.58 \mathrm{ppmv})$, peak values appeared at $10 \mathrm{~min}$ after the coal loading. The rates of decrease for the carbonyls after their peak values were much slower than those for aromatics, alkanes and alkenes, indicating that the carbonyls were produced mainly from secondary formation. The large difference in the emissions of NMHCs and carbonyls between the smoldering and flaming combustion processes indicated that both combustion 


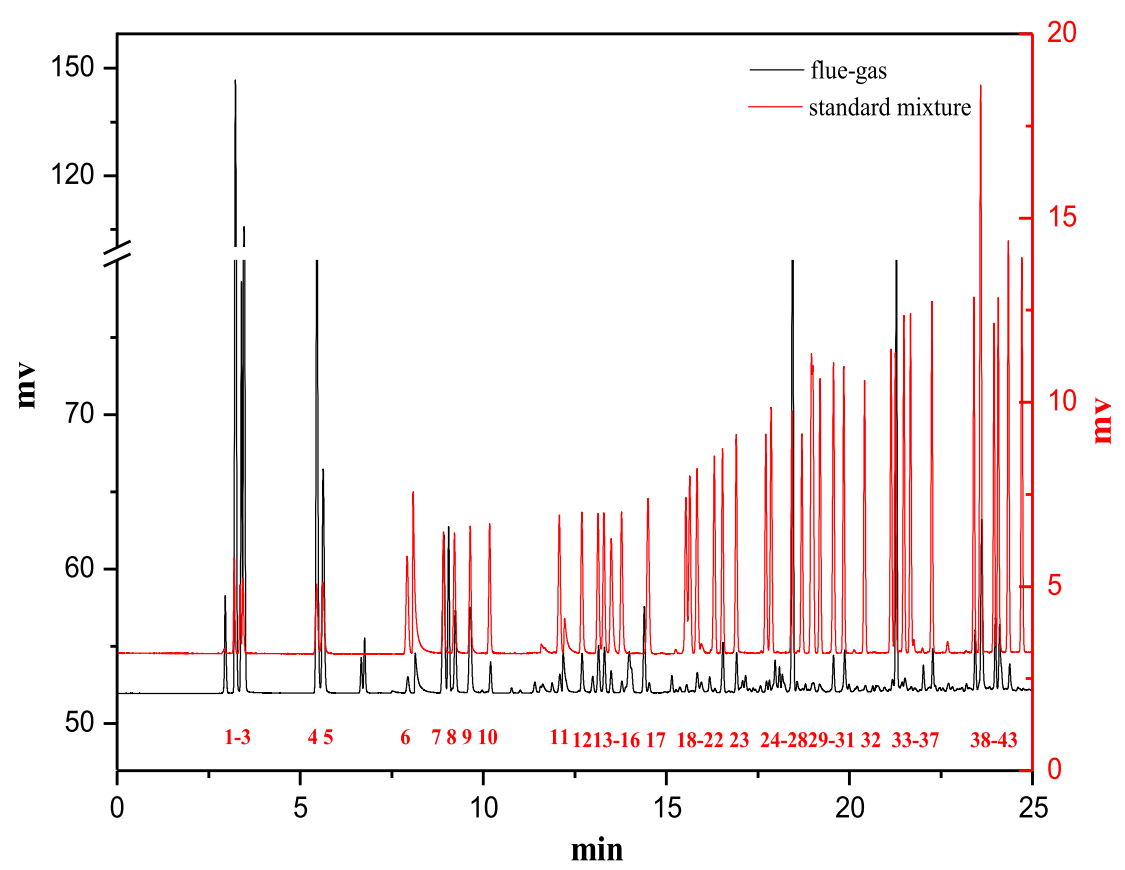

Fig. 2. Chromatograms of NMHCs in the flue-gas from the domestic coal stove and the standard mixture (Numbers refer to the substances presented in Table 2).
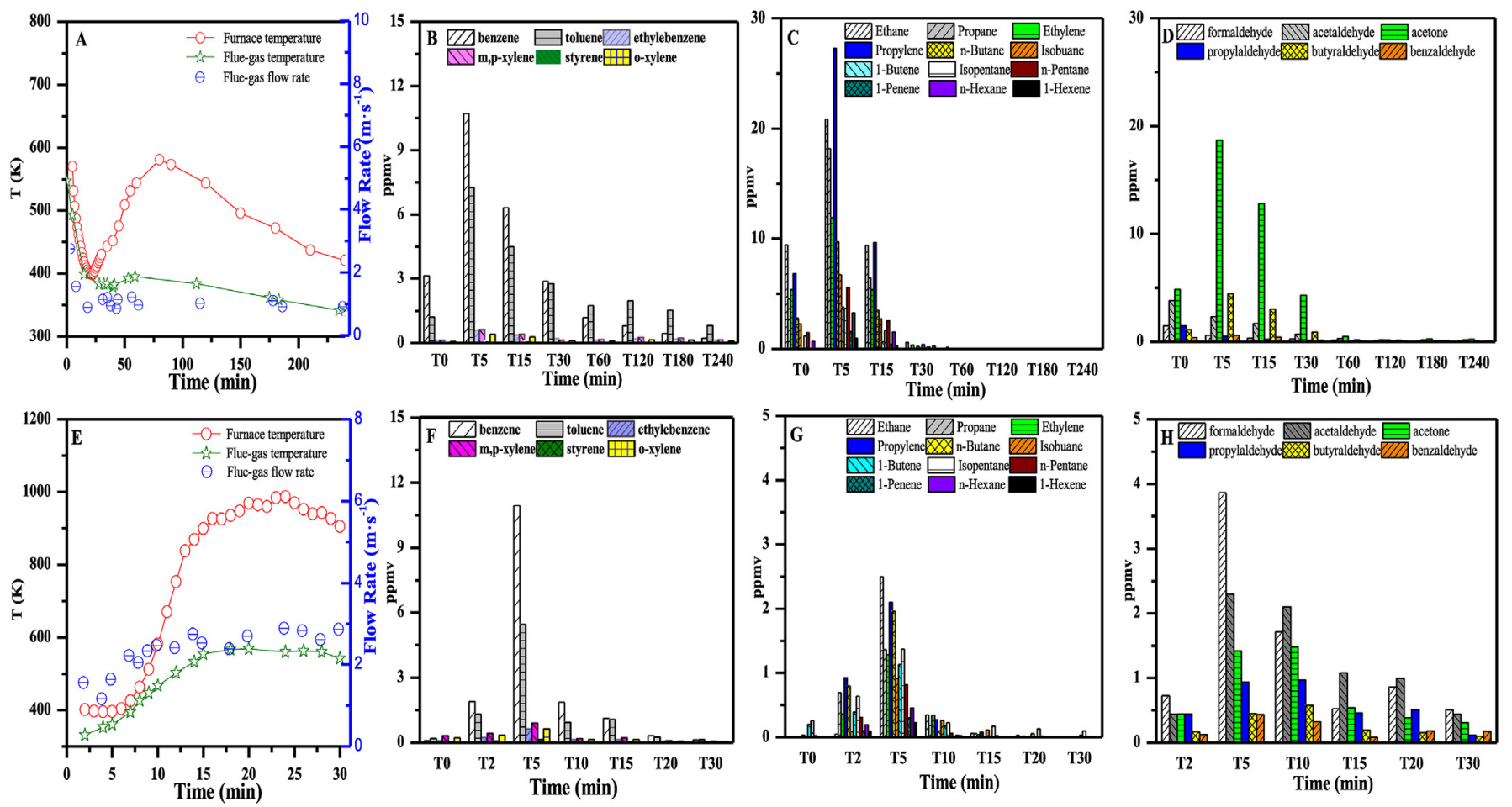

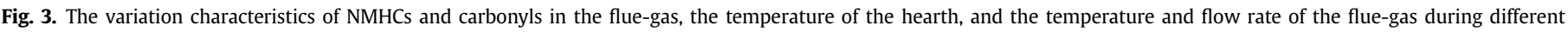
burning modes: A-D, smoldering combustion process; E-H, flaming combustion process.

processes should be considered in the estimate of the contribution of coal combustion to atmospheric NMHCs and carbonyls.

\subsection{Composition of VOCs in the flue-gas}

The individual weight percentages of the ten most abundant VOCs under the smoldering and flaming combustion processes are illustrated in Table 1. Under both combustion processes, ethane, benzene, toluene, ethylene, propane, propylene and acetone were found to be the common species in the top ten VOCs, which accounted for $77-78 \%$ of the total amount of VOCs, and ethane was the most abundant species. M,p-xylene, n-butane and 1-butene were among the top ten VOCs during the smoldering combustion process, while acetaldehyde, acetylene and propionaldehyde appeared in the top ten VOCs during the flaming combustion process. With the exception of ethane, the order of the weight 
Table 1

The ten most abundant VOCs species and their contributions to the total VOCs emissions during different burning modes.

\begin{tabular}{|c|c|c|c|c|c|c|c|c|c|}
\hline \multirow{2}{*}{\multicolumn{2}{|c|}{$\begin{array}{l}\text { Smoldering combustion } \\
\text { process (this study) }\end{array}$}} & \multicolumn{8}{|c|}{ Flaming combustion process } \\
\hline & & \multicolumn{2}{|l|}{ This study } & \multicolumn{2}{|c|}{ (Tsai et al., 2003) } & \multicolumn{2}{|c|}{ (Wang et al., 2013) } & \multicolumn{2}{|c|}{ (Liu et al., 2008b) } \\
\hline $\begin{array}{l}\text { VOCs } \\
\text { Species }\end{array}$ & $\begin{array}{l}\text { Percentage } \\
1 \%\end{array}$ & $\begin{array}{l}\text { VOCs } \\
\text { species }\end{array}$ & $\begin{array}{l}\text { Percentage } \\
1 \%\end{array}$ & $\begin{array}{l}\text { VOCs } \\
\text { species }\end{array}$ & $\begin{array}{l}\text { Percentage } \\
1 \%\end{array}$ & $\begin{array}{l}\text { VOCs } \\
\text { species }\end{array}$ & $\begin{array}{l}\text { Percentage } \\
/ \%\end{array}$ & VOCs species & $\begin{array}{l}\text { Percentage } \\
1 \%\end{array}$ \\
\hline Ethane & 19.73 & Ethane & 17.51 & Ethylene & 18.25 & Ethylene & 19.20 & Acetylene & 20.30 \\
\hline Benzene & 11.52 & Ethylene & 14.43 & Benzene & 15.23 & Formaldehyde & 11.80 & Ethylene & 8.80 \\
\hline Toluene & 10.21 & Benzene & 10.41 & Ethane & 14.44 & Acetone & 10.10 & Propane & 8.10 \\
\hline Ethylene & 9.15 & Propylene & 7.69 & Propene & 7.80 & Acetylene & 8.40 & Propylene & 7.40 \\
\hline Propane & 8.78 & Propane & 6.04 & Toluene & 7.63 & Ethane & 7.40 & Toluene & 7.30 \\
\hline Propylene & 7.26 & Toluene & 5.45 & m,p-Xylenes & 7.02 & Benzene & 6.00 & Benzene & 6.00 \\
\hline m,p-Xylene & 3.10 & Acetone & 5.28 & Propane & 4.88 & Acetaldehyde & 5.30 & $m, p$-Xylene & 3.70 \\
\hline Acetone & 3.09 & Acetylene & 4.60 & n-Decane & 3.66 & Propene & 2.80 & Butene & 3.20 \\
\hline n-Butane & 2.67 & Acetaldehyde & 3.47 & Acetylene & 3.52 & Butanal & 2.60 & Butane & 2.90 \\
\hline 1-Butene & 2.54 & Propylaldehyde & 2.07 & Nonane & 2.02 & Toluene & 2.10 & Pentane & 1.80 \\
\hline
\end{tabular}

percentages of the top ten VOCs was evidently different between the two combustion processes, e.g., ethylene ranked number 4 during the smoldering combustion process, whereas it ranked number 2 during the flaming combustion process. Therefore, the composition of VOCs emitted from domestic coal combustion strongly depended on the combustion conditions.

As shown in Table 1, acetylene, ethylene, propene, benzene and toluene were the common species among the top ten VOCs investigated by different laboratories (Tsai et al., 2003; Liu et al., 2008b; Wang et al., 2013). Both ethane and propane were found to be in the top ten VOCs in this study and the study of Tsai et al. (2003), whereas only ethane appeared in the top ten VOCs in the study of Wang et al. and only propane in the study of Liu et al. (2008b). M,pxylene was in the top ten VOCs (only including NMHCs) in the studies of Tsai et al. (2003) and Liu et al. (2008b), whereas it was not found in the top ten VOCs (including both NMHCs and carbonyls) in this study or in the study of Wang et al. (2013). Ethane was found to be the most abundant VOCs in this study, while ethylene was the most abundant species in the studies of Tsai et al. (2003) and Wang et al. (2013), and acetylene was the most abundant in the study of Liu et al. (2008b). As shown in Fig. 2G, the ratio of ethane/propane/ ethylene was $2.0 / 1.1 / 1.0$ at $5 \mathrm{~min}$ without flame, but it changed to 2.0/1.0/2.0 at $10 \mathrm{~min}$ with flame. In addition, the percentage of acetylene was obviously higher during flaming combustion than during smoldering combustion (Table 1 ). Therefore, the relatively higher rankings of ethylene and acetylene in the top ten VOCs in the studies of Tsai et al. (2003), Liu et al. (2008b) and Wang et al. (2013) were suspected to be attributed to the more completely coal combustion under their experimental conditions, e.g., Wang et al. (2013) conducted the experiments by adding 500-1000 g coal in eight batches, which favoured flaming combustion.

Acetone, acetaldehyde and propylaldehyde were in the top ten VOCs (including both NMHCs and carbonyls) in this study, whereas formaldehyde, acetone, acetaldehyde and butanal were in the top ten VOCs in the study of Wang et al. (2013). The EF $\left(41.9 \mathrm{mg} \mathrm{kg}^{-1}\right)$ of formaldehyde reported by Wang et al. (2013) was approximately a factor of 4 greater than that $\left(8.8 \pm 10 \mathrm{mg} \mathrm{kg}^{-1}\right)$ obtained in this study, which was probably due to the serious loss of formaldehyde on the sampling tube in the presence of condensation water under our field experimental conditions. However, the EFs of acetone $\left(29.5 \pm 7.7 \mathrm{mg} \mathrm{kg}^{-1}\right)$, acetaldehyde $\left(19.4 \pm 11.6 \mathrm{mg} \mathrm{kg}^{-1}\right)$ and butanal $\left(7.2 \pm 4.1 \mathrm{mg} \mathrm{kg}^{-1}\right)$ obtained in this study were in good agreement with those (acetone: $35.7 \mathrm{mg} \mathrm{kg}^{-1}$; acetaldehyde: $18.9 \mathrm{mg} \mathrm{kg}{ }^{-1}$; butanal: $9.38 \mathrm{mg} \mathrm{kg}^{-1}$ ) reported by Wang et al. (2013).

The VOCs measured were grouped into five categories: alkanes, acetylene, alkenes, aromatics and carbonyls, and their proportions to the total VOCs under the smoldering and flaming combustion processes are illustrated in Fig. 4. The order of the proportions under the smoldering combustion process was alkanes $>$ aromatics $>$ alkenes $>$ carbonyls $>$ acetylene, whereas under the flaming combustion process it was alkanes $>$ alkenes $>$ aromatics $>$ carbonyls $>$ acetylene. Compared with the smoldering combustion process, the proportions of alkenes, carbonyls and acetylene evidently increased during the flaming combustion, whereas obvious decrease for alkanes and aromatics. Aromatics and alkanes were suspected to be formed directly from pyrolysis of coal (Wang et al., 2015), whereas carbonyls were mainly from the oxidation of various organic compounds and alkenes might be from both the pyrolysis and the thermal dehydration of alkanols or alkanes during the combustion processes (Cathonnet, 2003; Bi et al., 2008). Because there was relatively less air supplied under the smoldering combustion process, VOCs emissions were dominated by the pyrolysis of coal, resulting in relatively high ratios of aromatics and alkanes. As for flaming combustion, aromatics and alkanes formed through the pyrolysis of coal could be quickly consumed via oxidation, and hence the additional formation channels for alkenes and carbonyls resulted in the increase of their proportions.

\subsection{Emission factors}

The average EFs of each identified compound in the flue-gas with five alternative combustion cycles (including smoldering combustion process and flaming combustion process) are listed in Table 2. It is evident that the EFs of the most VOCs and the EF of the total VOCS (TVOCs) during the smoldering combustion process were about one order of magnitude greater than those during the flaming combustion process, which indicated that VOCs emissions from domestic coal stoves were mainly focused on the smoldering combustion process. However, only few studies (Zhang et al., 2000; Tsai et al., 2003; Wang et al., 2013) investigated VOCs emissions from domestic coal stoves and all of them concentrated on the flaming combustion process (i.e. from fire start to fire extinction). In this study, the EFs of TVOCs during the flaming combustion and the smoldering combustion processes were approximately a factor of 1.6 and 15.9 greater than that $\left(337 \mathrm{mg} \mathrm{kg}^{-1}\right)$ reported by Wang et al. (2013), respectively. Tsai et al. (2003) reported that the EF of TNMHCs was $11.9 \mathrm{mg} \mathrm{kg}^{-1}$ for honeycomb coal briquette, $48.6 \mathrm{mg} \mathrm{kg}^{-1}$ for coal briquette, $4977 \mathrm{mg} \mathrm{kg}^{-1}$ for washed coal powder and $6480 \mathrm{mg} \mathrm{kg}^{-1}$ for unprocessed coal powder. The EFs of TNMHCs obtained by Tsai et al. (2003) for washed and unprocessed coal powder were about one order of magnitude greater than the EF of TVOCs obtained in this study during the flaming combustion process, whereas closed to the EF of TVOCs during the smoldering combustion process. 


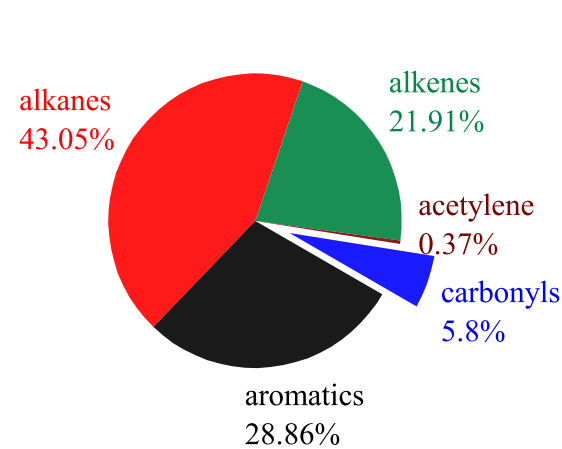

Smoldering combustion process

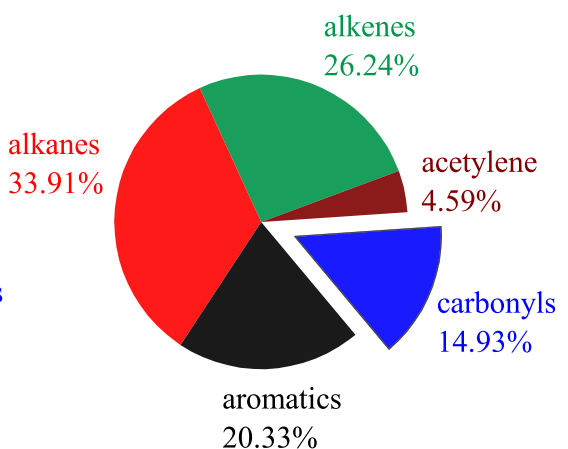

Flaming combustion process

Fig. 4. Chemical compositions of VOCs during different burning modes.

Table 2

Emission factors of VOCs emissions from the domestic coal stove during different burning modes (unit: $\mathrm{mg} \mathrm{kg}^{-1}$ ).

\begin{tabular}{|c|c|c|c|c|c|c|c|}
\hline \multicolumn{2}{|c|}{ No. Compound } & \multirow{2}{*}{$\begin{array}{l}\text { Smoldering combustion } \\
\text { process } \\
(\mathrm{n}=5)\end{array}$} & \multirow{2}{*}{$\begin{array}{l}\text { Flaming combustion } \\
\text { process } \\
(\mathrm{n}=5)\end{array}$} & \multirow[t]{2}{*}{ No. } & \multirow[t]{2}{*}{ Compound } & \multirow{2}{*}{$\begin{array}{l}\text { Smoldering combustion } \\
\text { process } \\
(\mathrm{n}=5)\end{array}$} & \multirow{2}{*}{$\begin{array}{l}\text { Flaming combustion } \\
\text { process } \\
(n=5)\end{array}$} \\
\hline & & & & & & & \\
\hline 1 & Ethylene & $494.5 \pm 127.2$ & $80.7 \pm 35.2$ & 26 & Benzene & $622.2 \pm 512.1$ & $58.2 \pm 34.8$ \\
\hline 2 & Acetylene & $18.2 \pm 2.4$ & $25.7 \pm 5.9$ & 27 & Cyclohexane & $9.6 \pm 1.8$ & $1.2 \pm 0.6$ \\
\hline 3 & Ethane & $1066.1 \pm 609.5$ & $97.9 \pm 86.8$ & 28 & $\begin{array}{l}\text { 2-Methylhexane and 2,3- } \\
\text { Dimethylpentane }\end{array}$ & $5.7 \pm 3.6$ & $0.6 \pm 0.6$ \\
\hline 4 & Propylene & $392 \pm 228.1$ & $43 \pm 43.2$ & 29 & 3-Methylhexane & $12.5 \pm 2.8$ & $1.2 \pm 1.1$ \\
\hline 5 & Propane & $474.3 \pm 275.9$ & $33.8 \pm 34$ & 30 & 2,2,4-Trimethylpentane & $20.2 \pm 25.6$ & $2.4 \pm 2.2$ \\
\hline 6 & Isobutane & $72 \pm 17$ & $6.2 \pm 7.9$ & 31 & n-Heptane & $67.7 \pm 31.3$ & $4.7 \pm 3.9$ \\
\hline 7 & 1-Butene & $137.5 \pm 28.8$ & $11.1 \pm 11.5$ & 32 & Methylcyclohexane & $7.2 \pm 2.6$ & $0.7 \pm 0.8$ \\
\hline 8 & n-Butane & $144.1 \pm 25.8$ & $9.8 \pm 8$ & 33 & 2,3,4-Trimethylpentane & nd & nd \\
\hline 9 & Trans-2-Butene & $35 \pm 4.7$ & $2.4 \pm 2.6$ & 34 & Toluene & $551.7 \pm 288.4$ & $30.5 \pm 29.3$ \\
\hline 10 & Cis-2-Butene & $19.6 \pm 9.2$ & $1.2 \pm 1.8$ & 35 & 2-Methylheptane & $10.9 \pm 1.6$ & $0.7 \pm 0.6$ \\
\hline 11 & Isopentane & $78.1 \pm 29.9$ & $7.5 \pm 4.9$ & 36 & 3-Methylheptane & nd & nd \\
\hline 12 & 1-Penene & $46.7 \pm 9.1$ & $3.1 \pm 3.2$ & 37 & n-Octane & $65.1 \pm 14.1$ & $4.1 \pm 2.9$ \\
\hline 13 & n-Pentane & $101.8 \pm 30.6$ & $6.4 \pm 5.8$ & 38 & Ethylbenzene & $80.4 \pm 29.4$ & $6.3 \pm 4$ \\
\hline 14 & Isoprene & $2.1 \pm 1.7$ & nd & 39,40 & m,p-Xylene & $167.4 \pm 81.4$ & $9.8 \pm 7.1$ \\
\hline 15 & Trans-2-Pentene & $16.2 \pm 24.4$ & $1 \pm 1.4$ & 41 & Styrene & $26.3 \pm 25.1$ & $1.6 \pm 0.8$ \\
\hline 16 & Cis-2-Pentene & $9.7 \pm 6.7$ & $0.7 \pm 0.8$ & 42 & o-Xylene & $110.9 \pm 72.9$ & $7.3 \pm 5.7$ \\
\hline 17 & 2,2-Dimethylbutane & $3.2 \pm 9.3$ & nd & 43 & Nonane & $67.3 \pm 8.1$ & $4.1 \pm 2.6$ \\
\hline 18 & Cyclopentane & nd & nd & 44 & Formaldehyde & $12.6 \pm 3.2$ & $8.8 \pm 10$ \\
\hline 19 & 2,3-Dimethylbutane & nd & nd & 45 & Acetaldehyde & $33.5 \pm 6.5$ & $19.4 \pm 11.6$ \\
\hline 20 & 2-Methylpentane & $25.8 \pm 14.8$ & $1.9 \pm 1.4$ & 46 & Acetone & $166.8 \pm 63.9$ & $29.5 \pm 7.7$ \\
\hline 21 & 3-Methylpentane & $3.3 \pm 3.8$ & $0.6 \pm 0.7$ & 47 & Propionaldehyde & $20.8 \pm 9.3$ & $11.6 \pm 7.6$ \\
\hline 22 & 1-Hexene & $32.2 \pm 35.8$ & $3.6 \pm 3.5$ & 48 & Butyraldehyde & $52.2 \pm 25.7$ & $7.2 \pm 4.1$ \\
\hline 23 & n-Hexane & $75 \pm 23$ & $4.6 \pm 4.2$ & 49 & Benzaldehyde & $27.5 \pm 11.2$ & $6.9 \pm 4.6$ \\
\hline 24 & Methylcyclopentane & $13.7 \pm 13.2$ & $1.1 \pm 1.3$ & 50 & TVOCs & $5402.9 \pm 2031.8$ & $559.2 \pm 385.9$ \\
\hline 25 & $\begin{array}{l}\text { 2,4- } \\
\text { Dimethylpentane }\end{array}$ & $1.6 \pm 4.6$ & nd & & & & \\
\hline
\end{tabular}

*nd $=$ not detected.

As domestic coal stoves constructed via layer combustion technology are commonly used by farmers and as raw bituminous coal accounts for the largest fraction of domestic coal consumption in China, the EF of VOCs obtained in this study could be representative for estimating VOCs emission from domestic coal stoves. The China National Bureau of Statistics reported that the domestic coal consumption in the Beijing-Tianjin-Hebei area was approximately $2.0 \times 10^{10} \mathrm{~kg} \mathrm{yr}^{-1}$ (China National Bureau of Statistics, 2014), while the most recent investigation (http://www.qstheory.cn/st/dfst/ 201306/t20130607_238302.htm) revealed that the actual domestic coal consumption in the area was about $4.2 \times 10^{10} \mathrm{~kg} \mathrm{yr}^{-1}$. Based on the most recent domestic coal consumption $\left(4.2 \times 10^{10} \mathrm{~kg} \mathrm{a}^{-1}\right)$ and the average EF of VOCs (2981.1 $\mathrm{mg} \mathrm{kg}^{-1}$ ) obtained from both combustion processes in the situ, VOCs emissions from domestic coal stoves in the region of Beijing-Tianjin-Hebei was estimated to be $1.25 \times 10^{8} \mathrm{~kg} \mathrm{a}^{-1}$ which was approximately a factor of 64 greater than the value $\left(1.95 \times 10^{6} \mathrm{~kg} \mathrm{a}^{-1}\right)$ estimated from the power plant based on the EF of $150 \mathrm{mg} \mathrm{kg}^{-1}$ for the power plant (Bo et al., 2008) and the thermal coal consumption value of $1.3 \times 10^{10} \mathrm{~kg} \mathrm{a}^{-1}$ in the region (Wang and Ducruet, 2014). Therefore, the extremely high VOCs emissions from domestic coal combustion should be aroused attention for improving the regional air quality.

\section{Conclusion}

The emission peaks of VOCs occurred in the early combustion stage after the coal loading during both flaming and smoldering combustion processes, which were ascribed to the transient extinguishing of the flame due to fresh coal loading. The top ten VOCs species and their orders were evidently different between the two combustion processes, implying that the combustion mode was an important factor in the proportions of VOCs emissions. The EFs of TVOCs under smoldering combustion process were nearly one order of magnitude greater than those under the flaming 
combustion process, indicating that VOCs emissions from domestic coal stoves were mainly attributed to the smoldering combustion process. The TVOCs emission from domestic coal combustion was estimated to be approximately a factor of 64 greater than the value estimated from the power plant in the region of Beijing-TianjinHebei, showing that domestic coal combustion contributes remarkably to atmospheric VOCs in the region.

\section{Acknowledgements}

This work was supported by the National Natural Science Foundation of China (No. 91544211, 21477142, 41575121), by Strategic Priority Research Program projects (B) of the Chinese Academy of Sciences (No. XDB05010100), and by the Special Fund for Environmental Research in the Public Interest (No. 201509002).

\section{References}

Barreca, A., Clay, K., Tarr, J., 2014. Coal, Smoke, and Death: Bituminous Coal and American Home Heating. NBER Working Paper, No. 19881.

Ben, H., Kayoko, K., 2015. The energy consumption of heating in the Northeast rural area of China from the perspective of the kang and agricultural waste. Meteorol. Environ. Res. 6, 9-13.

Bo, Y., Cai, H., Xie, S., 2008. Spatial and temporal variation of historical anthropogenic NMVOCs emission inventories in China. Atmos. Chem. Phys. 8, 7297-7316.

Bi, X., Simoneit, B.R.T., Sheng, G., Fu, J., 2008. Characterization of molecular markers in smoke from residential coal combustion in China. Fuel 87, 112-119.

Bond, T.C., Streets, D.G., Yarber, K.F., Nelson, S.M., Woo, J.H., Klimont, Z., 2004 A technology-based global inventory of black and organic carbon emissions from combustion. J. Geophys. Res. 109, D14203.

Boynard, A., Clerbaux, C., Clarisse, L., Safieddine, S., Pommier, M., Van Damme, M., Bauduin, S., Oudot, C., Hadji-Lazaro, J., Hurtmans, D., 2014. First simultaneous space measurements of atmospheric pollutants in the boundary layer from IASI: a case study in the North China Plain. Geophys. Res. Lett. 41, 645-651.

Cathonnet M., 2003. Advances and challenges in the chemical kinetics of combustion. Proceedings of the European Combustion Meeting 2003.

Chen, Y.J., Bi, X.H., Mai, B.X., Sheng, G.Y., Fu, J.M., 2004. Emission characterization of particulate/gaseous phases and size association for polycyclic aromatic hydrocarbons from residential coal combustion. Fuel 83, 781-790.

Chen, Y.J., Sheng, G.Y., Bi, X.H., Feng, Y.L., Mai, B.X., Fu, J.M., 2005. Emission factors for carbonaceous particles and polycyclic aromatic hydrocarbons from residential coal combustion in China. Environ. Sci. Technol. 39, 1861-1867.

China National Bureau of Statistics, 2014. China Energy Statistical Yearbook 2013. China Stat. Press, Beijing.

Du, Q.Q., Zhang, C.L., Mu, Y.J., Cheng, Y., Zhang, Y.Y., Liu, C.T., Song, M., Tian, D., Liu, P.F., Liu, J.F., Xue, C.Y., Ye, C., 2016. An important missing source of atmospheric carbonyl sulfide: domestic coal combustion. Geophys. Res. Lett. 43, 8720-8727.

Dong, G.H., Qian, Z., Wang, J., Trevathan, E., Ma, W., Chen, W., Xaverius, P.K. Buckner-Petty, S., Ray, A., Liu, M.M., Wang, D., Ren, W.H., Emo, B., Chang, J.J., 2013. Residential characteristics and household risk factors and respiratory diseases in Chinese women: the Seven Northeast Cities (SNEC) Study. Sci. Total Environ. 463-464, 389-394.

EPA, 1999. Compendium of methods for the determination of toxic organic compounds in ambient air (2nd ed.).

Finkelman, R.B., Belkin, H.E., Zheng, B.S., 1999. Health impacts of domestic coal use in China. Proc. Natl. Acad. Sci. U. S. A. 96, 3427-3431.

Finkelman, R.B., Orem, W., Castranova, V., Tatu, C.A., Belkin, H.E., Zheng, B. Lerch, H.E., Maharaj, S.V., Bates, A.L., 2002. Health impacts of coal and coal use: possible solutions. Int. J. Coal Geol. 50, 425-443.

Gaffney, J.S., Marley, N.A., 2009. The impacts of combustion emissions on air quality and climate - from coal to biofuels and beyond. Atmos. Environ. 43, 23-36.

Hosgood, H.D., Wei, H., Sapkota, A., Choudhury, I., Bruce, N., Smith, K.R. Rothman, N., Lan, Q., 2011. Household coal use and lung cancer: systematic review and meta-analysis of case-control studies, with an emphasis on geographic variation. Int. J. Epidemiol. 40, 719-728.

Hosgood, H.D., Chapman, R.S., He, X., Hu, W., Tian, L., Liu, L.Z., Lai, H., Chen, W. Rothman, N., Lan, Q., 2013. History of lung disease and risk of lung cancer in a population with high household fuel combustion exposures in rural China. Lung Cancer 81, 343-346.

Huang, W., Huang, B., Bi, X., Lin, Q., Liu, M., Ren, Z., Zhang, G., Wang, X., Sheng, G., Fu, J., 2014a. Emission of PAHs, NPAHs and OPAHs from residential honeycomb coal briquette combustion. Energy Fuel 28, 636-642.

Huang, R.J., Zhang, Y., Bozzetti, C., Ho, K.F., Cao, J.J., Han, Y., Daellenbach, K.R. Slowik, J.G., Platt, S.M., Canonaco, F., 2014b. High secondary aeroso contribution to particulate pollution during haze events in China. Nature 514, $218-222$.

Lee, R.G., Coleman, P., Jones, J.L., Jones, K.C., Lohmann, R., 2005. Emission factors and importance of PCDD/Fs, PCBs, PCNs, PAHs and PM10 from the domestic burning of coal and wood in the UK. Environ. Sci. Technol. 39, 1436-1447.

Li, J., Xie, S., Zeng, L., Li, L., Li, Y., Wu, R., 2015. Characterization of ambient volatile organic compounds and their sources in Beijing, before, during, and after AsiaPacific Economic Cooperation China 2014. Atmos. Chem. Phys. 15, 7945-7959.

Li, W., Wang, C., Wang, H., Chen, J., Shen, H., Shen, G., Huang, Y., Wang, R., Wang, B., Zhang, Y., 2014a. Atmospheric polycyclic aromatic hydrocarbons in rural and urban areas of northern China. Environ. Pollut. 192, 83-90.

Li, W., Wang, C., Wang, H., Chen, J., Yuan, C., Li, T., Wang, W., Shen, H., Huang, Y., Wang, R., 2014b. Distribution of atmospheric particulate matter (PM) in rural field, rural village and urban areas of northern China. Environ. Pollut. 185, 134-140.

Liu, C., Mu, Y., Zhang, C., Zhang, Z., Zhang, Y., Liu, J., Sheng, J., Quan, J., 2016. Development of gas chromatography-flame ionization detection system with a single column and liquid nitrogen-free for measuring atmospheric C2-C12 hydrocarbons. J. Chromatogr. A 1427, 134-141.

Liu, S., Tao, S., Liu, W., Dou, H., Liu, Y., Zhao, J., Little, M.G., Tian, Z., Wang, J., Wang, L., Gao, Y., 2008a. Seasonal and spatial occurrence and distribution of atmospheric polycyclic aromatic hydrocarbons (PAHs) in rural and urban areas of the North Chinese Plain. Environ. Pollut. 156, 651-656.

Liu, Y., Shao, M., Fu, L.L., Lu, S.H., Zeng, L.M., Tang, D.G., 2008b. Source profiles of volatile organic compounds (VOCs) measured in China: Part I. Atmos. Environ. 42, 6247-6260.

Møller, P., Folkmann, J.K., Forchhammer, L., Bräuner, E.V., Danielsen, P.H., Risom, L., Loft, S., 2008. Air pollution, oxidative damage to DNA, and carcinogenesis. Cancer Lett. 266, 84-97.

Oros, D.R., Simoneit, B.R.T., 2000. Identification and emission rates of molecular tracers in coal smoke particulate matter. Fuel 79, 515-536.

Pandit, G.G., Srivastava, P.K., Mohan Rao, A.M., 2001. Monitoring of indoor volatile organic compounds and polycyclic aromatic hydrocarbons arising from kerosene cooking fuel. Sci. Total Environ. 279, 159-165.

Pang, X., Mu, Y., 2006. Seasonal and diurnal variations of carbonyl compounds in Beijing ambient air. Atmos. Environ. 40, 6313-6320.

Pang, X., Mu, Y., 2007. Characteristics of carbonyl compounds in public vehicles of Beijing city: concentrations, sources, and personal exposures. Atmos. Environ. 41, 1819-1824.

Subbaraman, N., 2014. Public health: a burning issue. Nature 513, S16-S17.

Tao, M., Chen, L., Su, L., Tao, J., 2012. Satellite observation of regional haze pollution over the North China Plain. J. Geophys. Res. 117, D12203.

Tian, L.W., Lucas, D., Fischer, S.L., Lee, S.C., Hammond, S.K., Koshland, C.P., 2008. Particle and gas emissions from a simulated coal-burning household fire pit. Environ. Sci. Technol. 42, 2503-2508.

Tsai, S.M., Zhang, J.F., Smith, K.R., Ma, Y.Q., Rasmussen, R.A., Khalil, M.A.K., 2003. Characterization of non-methane hydrocarbons emitted from various cookstoves used in China. Environ. Sci. Technol. 37, 2869-2877.

Vanker, A., Barnett, W., Nduru, P.M., Gie, R.P., Sly, P.D., Zar, H.J., 2015. Home environment and indoor air pollution exposure in an African birth cohort study. Sci. Total Environ. 536, 362-367.

Wang, C., Ducruet, C., 2014. Transport corridors and regional balance in China: the case of coal trade and logistics. J. Transp. Geogr. 40, 3-16.

Wang, Q., Geng, C., Lu, S., Chen, W., Shao, M., 2013. Emission factors of gaseous carbonaceous species from residential combustion of coal and crop residue briquettes. Front. Environ. Sci. Eng. 7, 66-76.

Wang, X.F., Cotter, E., Iyer, K.N., Fang, J.X., Williams, B.J., Biswas, P., 2015. Relationship between pyrolysis products and organic aerosols formed during coal combustion. Proc. Combust. Inst. 35, 2347-2354.

Wang, Y., Xu, Y., Chen, Y., Tian, C., Feng, Y., Chen, T., Li, J., Zhang, G., et al., 2016. Influence of different types of coals and stoves on the emissions of parent and oxygenated PAHs from residential coal combustion in China. Environ. Pollut. $212,1-8$.

Xu, W., Zhao, C., Ran, L., Deng, Z., Liu, P., Ma, N., Lin, W., Xu, X., Yan, P., He, X., et al., 2011. Characteristics of pollutants and their correlation to meteorological conditions at a suburban site in the North China Plain. Atmos. Chem. Phys. 11, 4353-4369.

Zhang, H.F., Wang, S.X., Hao, J.M., Wan, L., Jiang, J.K., Zhang, M., Mestl, H.E.S., Alnes, L.W.H., Aunan, K. Mellouki, A.W., 2012. Chemical and size characterization of particles emitted from the burning of coal and wood in rural households in Guizhou, China. Atmos. Environ. 51, 94-99.

Zhang, J., Smith, K.R., Ma, Y., Ye, S., Jiang, F., Qi, W., Liu, P., Khalil, M.A.K., Rasmussen, R.A., Thorneloe, S.A., 2000. Greenhouse gases and other airborne pollutants from household stoves in China: a database for emission factors. Atmos. Environ. 34, 4537-4549.

Zhang, J.J., Smith, K.R., 2007. Household air pollution from coal and biomass fuels in China: measurements, health impacts, and interventions. Environ. Health Persp. $115,848-855$.

Zhang, Y., Schauer, J.J., Zhang, Y., Zeng, L., Wei, Y., Liu, Y., Shao, M., 2008. Characteristics of particulate carbon emissions from real-world Chinese coal combustion. Environ. Sci. Technol. 42, 5068-5073. 